\title{
Assessing the Impact of Operational Flaws on the Performance of Microfinance Institutions in Ghana
}

\author{
Adjei Gyamfi Gyimah (Corresponding author) \\ Supply Chain and Business Linkage Department, Competitive cashew initiative, German \\ Development Cooperation (GIZ), Accra, Ghana \\ E-mail: adjei195@yahoo.co.uk \\ Annette Serwaa Agyeman \\ School of Finance, Zhongnan University of Economics and Law, Wuhan, China \\ Solomon Adu-Asare \\ Frontline Capital Advisors, Accra, Ghana
}

Received: November 13, 2019

Accepted: March 7, 2020 Published: April 2, 2020

doi:10.5296/ifb.v7i1.15753

URL: http://dx.doi.org/10.5296/ifb.v7i1.15753

\begin{abstract}
Microfinance institutions contribute significantly to the development of a country, and many of these institutions are found in most developing countries including Ghana. However, many challenges have been alleged to stifle the efforts of microfinance companies in their attempt to make their all-important contribution to the development of nations. This study explored the effect of operational flaws on the performance of microfinance institutions in Ghana. The results discovered flaws and challenges associated with the operations of the MFIs in many areas including corporate governance, credit risk management, credit administration, regulatory challenges, and training programs. The study also revealed that such flaws and challenges do harm the overall performance of the MFIs. Based on the findings, it is recommended that MFIs put in place a well-composed and resourceful credit committee to perform the duty of credit risk management in the institutions. The institutions could also reduce their interest rates to encourage their clients to apply for more loans. Lastly, it is recommended that the MFIs take all necessary steps to ensure that they reduce the flaws and challenges they face to mitigate the negative impact of such deficiencies on their performance.
\end{abstract}

Keywords: Operational flaws, microfinance institutions, performance, Ghana 


\section{Introduction}

The life cycle of a business, just like that of a human being, goes through many stages. Just as a person is born, grows to maturity, and dies, business entities pass through the same stages. Although business experts disagree on the number of distinct stages in a business life cycle, they typically agree on what occurs during each critical stage. Small scale businesses require financial assistance to grow, but their nature makes it so difficult for them to access credit facilities from the mainstream or formal financial sector as a result of their inability to provide collateral. Financial and institutional development helps improve SMEs' growth constraints and increase their access to external finance, mostly through the activities of Micro-Credit or Microfinance Institutions (Ferrando et al., 2017).

According to the Ghana Population and Housing Census in the year 2000, 80\% of the working population are found in the private informal sector (Arku et al., 2016). This group is characterized by lack of access to credit, which constrains the development and growth of that sector of the economy. The observation was stressed in the May 2013 International Monetary Fund Country report on Ghana that "weaknesses in the financial sector that restrict financing opportunities for productive private investment are a particular impediment to business expansion in Ghana" sector. Access to financial services is imperative for the development of the informal sector and also help to mop up excess liquidity through savings that can be made available as investment capital for national development (Bannò et al., 2014)

Despite financial reforms, the Ghanaian financial sector still experiences a gap between the demand for and the supply of financial services, and conventional financial services are designed with the self-sufficient populace in mind. MFIs have led the way in catering for the financial needs of the poor populace intentionally ignored by conventional financial institutions. The manifestation of the poor people that they can be reliable as bank customers is the supreme achievement of micro-financing. Microfinance has been an important tool for economic empowerment and poverty alleviation, especially in Africa, Asia, and other underdeveloped countries in other continents (Donou-Adonsou \& Sylwester, 2016; Addai, 2017).

The enormous benefit of MFIs to the development and empowerment of the poor cannot be underestimated, but their activities is bedeviled by a lot of flaws (Shah \& Patel, 2017). Challenges in Microfinance in Ghana have threatened depositors' funds, thus eroding public confidence and undermining efforts to promote financial inclusion. To restore public confidence, the Bank of Ghana between February 2019 and August 2019 embarked on a "clean-up" exercise, thereby revoking the licenses of 23 savings and loans institutions and 347 microfinance institutions.

Given these developments, this study sought to provide an update of recent developments in the microfinance sub-sector in Ghana, principally drawing out the key challenges of microfinance clients and borrowers, and the present operational flaws of the microfinance institutions. This study, therefore, bridges the informational gap in microfinance literature as most of the existing works on microfinance have ignored investigations into the operational 
flaws in these institutions. Fresh insight and the most recent dynamics that have surfaced in microfinance operations are presented in this study. Additionally, this study is conducted against the backdrop that the microfinance sector in Ghana is currently at a make-or-break point in its existence. The subsequent sections present: research objectives; review of relevant theory and literature, prior empirical studies, the research methodology, data analyses, and the conclusion of the entire study.

\section{Literature Review}

This section presents a review of prior literature on Microfinance, including theoretical review, the development of MFIs; Microfinance in developed and developing countries; operational flaws, and challenges facing clients of MFIs.

\subsection{Theoretical Review}

The following theories have collectively formed a basis for this study; Theory of Change and the Loanable Funds Theory.

The theory of change (ToC) is an on-going process of reflection to explore change, why it happens and how it happens - and what that means in a particular context, sector, and/or group of people. It also embodies why change works or otherwise (J-PAL, 2014). This theory has become a popular development tool for most development organizations in bringing structure and clarity to development interventions in many parts of the world. It offers a structured way of thinking about change and impact organizations like to achieve an integrated approach to program design, implementation, monitoring, and evaluation (M\&E), and communication (J-PAL, 2014). There are several potential levels of analysis when thinking practically about social change, from organizational to the societal, and from conceptualization to implementation. Though interconnected, defining the level(s) at which a ToC approach is meant to function is crucial for the clarity and practicality of a given ToC and its associated intervention (Stein \& Valters, 2000). Essentially, ToC is grounded in interventions, change and results. The present study is interested in the changes that have taken place in the operations of MFIs in Ghana over time, highlighting the flaws and how challenges facing the sub-sector for borrowers and MFIs have also changed over time.

The loanable funds theory (LFT) is a classical theory in which the rate of interest is determined by investment (demand for loans) and saving (the supply of loans) in an economy (Bertocco, 2007). The rate of interest is determined by the equilibrium between the level of saving and the level of investment. Figure 1 pictorially depicts the LFT. 


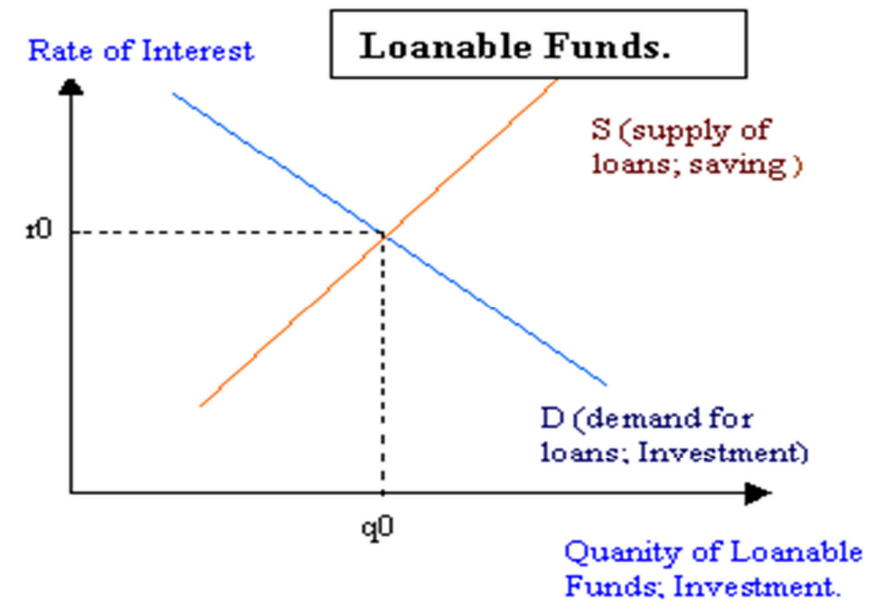

Figure 1. The Loanable Funds Theory (Source: kokminglee.125mb.com)

From Figure 1, D is downward sloping because a higher rate of interest means a higher (opportunity) cost to firms to finance investment. The higher cost also lowers profitability and in turn, lowers the demand for loans. The latter can be seen as the diminishing returns to investment. $\mathrm{S}$ is sloping upwards because a higher rate of interest means households have a greater incentive to save, other things being equal. The shift in $\mathrm{S}$ is explained by time preference. When households are not in a rush to consume, they are assumed to have a low time preference, thus more saving. In reality, however, the current level of saving is not the quantity of loanable funds supplied. Savings over the supply of loanable funds could be stored away as Excess Reserves (liquidity) by banks. The LFT explains how the rate of interest is determined in a simple economy in which the supply of money comes from savings, and demand for money is for investment. If the rate of interest were above $\mathrm{r} 0$, then the quantity of loanable funds supplied is larger than the quantity demanded by firms. Banks will have to lower the rate of interest to attract more borrowing. Similarly, if the rate of interest were below $\mathrm{r} 0$, then the quantity demanded is larger than the quantity supplied. Thus, banks will have to raise the rate of interest to attract more saving to re-establish equilibrium.

\subsection{The Development of Microfinance Institutions (MFIs)}

Friedrich Wilhelm Raiffeisen and his followers established the credit union idea in Europe in the 1800s. Their selfless thought was inspired by a desire to help the rural population break out and boost their wellbeing from their reliance on money-lenders.

Starting in the 1970s, pioneering projects in Bangladesh, notably by one of the founders of modern microfinance, Muhammad Yunus, helped push the industry even further into the spotlight. In order to invest in micro-enterprises, small loans are distributed to groups of poor women. This form of micro-loan was focused on communal principles with every member of a group.

Ghana set up the Microfinance and Small Loans Centre (MASLOC) in 2006 in the spirit of micro-enterprise finance. The private MFIs are usually profit-oriented while the non-profit 
MFIs are normally Non-Governmental Organizations (NGOs) funded by international partners and donors.

MFIs are important because of the issue that low-income individuals pay high prices and sometimes rely on unreliable, volatile and devious alternatives for accessing simple finance-related services. (CGAP, 2015).

\subsection{MFIs in Ghana}

It has always been a common practice for people to save and/or take small loans from individuals and groups within the context of self-help to engage in small retail businesses or farming ventures. Egyir (2010) notes that before formal banking systems in Ghana, many of the poor, mainly women, and those in rural communities, relied heavily on informal banking services and the semi-formal savings and loans schemes. There is a long history of informal alternatives of credit and savings, especially among women petty traders and women with small off-farm business needs. They included Susu groups, Susu collectors, and moneylenders.

Over the years, the microfinance sector has thrived and evolved into its current state due to various financial sector policies and programs undertaken by different governments since independence. In terms of the regulatory framework, rural and community banks are regulated under the Banking Act 2004 (Act 673) as amended by Banking Act 2007 (Act 738), while the Savings and Loans Companies are currently regulated under the Non-Bank Financial Institutions (NBFI) Act 2008 (Act 774). Until July 2011, there had been no regulatory framework for the rest of the players, such as the financial non-governmental organizations and moneylenders.

Boateng (2015) asserts that MFIs were founded because of the perceived deficiencies in the existing financing schemes for the poor and small businesses. New companies were licensed to begin operations in 2011, and existing institutions and Non-deposit taking Financial Non-Governmental Organizations (FNGOs) that met the conditions spelled out by Bank of Ghana (BoG) for licensing were allowed to metamorphose into MFIs.

\subsection{The Activities and Role of Mfis}

MFIs play a key role in providing services to those excluded from financial services, especially the poor and the informal sector. The following addresses some of MFI's major services. Moreover, the allocation of resources for their business activities to the successful poor is a major step towards achieving this goal. MFIs provide the masses with funds in the form of capital, microloans and human resource empowerment through training with the end of poverty alleviation (Okezie et al., 2014). Also, when capital funds are given by MFIs; jobs are consequently created. Recipients of microloans create business opportunities which create jobs. Besides the main enterprises run by fund recipients and borrowers, ancillary or related industries benefit by offering services which drive expansion and hence, multiple employment.

Furthermore, MFIs contribute to business development of their clients by offering marketing training, book keeping and record keeping, cashflow management among others (Friends 
Consult, 2015). Additionally, it would be interesting to know how the financial self-sufficiency (FSS) of MFIs is impacted by their practices and activities in corporate social responsibility (CSR), a consideration not too pronounced in empirical works. MFIs have helped with community projects such as schools and boreholes. Medical insurance and medical bills have been settled by MFIs in some instances in Ghana.

Failure of microfinance schemes at state level has been due to numerous challenges. The following are some challenges microfinance institutions face. Microfinance in most countries operated for decades since 1950 without regulations and proper guidelines. This is largely the reason for the chequered history and slow development of the sub-sector. A lack of methodological harmony in addressing microfinance challenges has slowed the search for appropriate policy guidelines (Asiama \& Osei, 2007).

Firms which have excessive trading activity usually encounter working capital and liquidity challenges. This begins a vicious cycle of ballooning interest expense and hence low net profit, reduced working capital, borrowings to make up cash shortfall which leads to increased interest expense to continue the cycle. Indulging excessively in trading is usually a result of incompetent staff. An example is a situation where funds which could have been invested to break even ends up being abused.

To attract funds, grow and expand in the face of competition, MFIs promise very high rates for fixed deposit investments. Owusu-Nuamah (2014) found that due to the proliferation of MFIs, the MFI market had become saturated. Many products to compete and attract funds had been developed.

Microfinance demands unique expertise and a mix of inter-disciplinary skills. Most individuals formed their own MFIs after working in top to middle level management in other MFIs. Some of these business promoters lacked a good appreciation of MFI operations and refused to listen to other MFI experts they consulted or employed. Such employees could not argue with the MFI owners and promoters in a bid to maintain their jobs. Longevity and superior performance is linked to healthy corporate governance. Corporate governance therefore remains a major challenge for microfinance in Ghana (Dato, 2018). The doubling of owners as managers and the missing independence of the board of most MFIs have been principal causes of business failure.

While interest income from loans have been the foremost contributor to MFI income, loan administration and credit departments have not been credited with the commensurate attention and analysis. The simple expedient of asking customers to save for a month or two and receive a double or triple size of their savings as loan amounts defeated the purpose of diligent loan assessment. Credit officers have been hard-pressed and cannot undertake patient due diligence on loan applications due to the high loan-officer-to-client ratio of MFIs companies as well as weak monitoring of aging loans for the same reasons. Clients who knew this weakness exploited it by moral hazard thereby leading to high loan defaults.

Mukama et al. (2005) established that employee indicators, such as their level of education, skills, and the nature of employee incentive schemes could influence the longevity of MFIs. It 
is worth noting that fraud perpetrated by employees, and for that matter insiders, have been a result of poor internal controls, improper record and bookkeeping and lax supervision (Kumar \& Conteh, 2015). There have been cases where MFI employees have created fictitious accounts to take loans, create non-existent expenses, omit transactions or erase transactions.

\subsection{Challenges Facing Clients of MFIs}

Several researchers have tried to identify the main challenges faced by the clients of microfinance institutions (MFIs), and they usually come to a similar conclusion. According to Addai (2017) and Wulandari and Kassim (2016), one of the major challenges faced by clients of microfinance institutions is the issue of collaterals. Most clients of MFIs are unable to afford the collateral demanded by the MFIs especially if the clients demand higher amounts. This scenario does not only cause the institutions to lose profits but, in a more grievous scenario, causes the MFIs to lose their clients.

Another major challenge that usually confronts clients of MFIs is high-interest rates. According to Mia (2017) and Shah \& Patel (2017), the interest rate charged by microfinance companies is usually on the high side, usually due to the risks associated with their credit facilities. High-interest rate is one of the major causes of the inability of clients of MFIs to fulfill their financial obligations towards the MFIs. A reduction in the interest rates of the MFIs is, therefore, necessary for ensuring that the clients can keep up with their payments.

According to Anitha \& Reddy (2017), delay in the processing of loan facilities for clients of microfinance companies is another challenge usually reported by clients of the institutions. They, therefore, were of the view that it is necessary for MFIs to, as much as possible, expedite the procedure for granting credit facilities to clients.

Also, it has been strongly asserted by several researchers, including Flora (2015) and Couchoro (2016), that clients of MFIs who typically have low levels of education are likely to face challenges as to how to manage whatever credit advanced to them. Thus, the need to give the clients of the MFIs some form of financial education is necessary for them to use the credit facilities given to them judiciously.

Lastly, even though short loan repayment time frames are considered a credit risk management practice by most MFIs, the businesses of some clients might need a much longer time frame to yield benefits that could enable the clients to pay back what they owe the MFIs (Wulandari \& Kassim, 2016).

\section{Research Methodology}

The study was conducted among staff and clients of three selected MFIs, namely: International Savings and Loans Limited (OISL); Noble Dream Microfinance Limited (NDML), and JEFAM Microfinance Company Limited (JMCL). Random sampling was used to select 45 staff of the selected MFIs (15 from each institution) and 45 clients of the three selected MFIs (15 clients from each institution). For lack of resources, the study was conducted with a small sample size. The research fundamentally made use of primary data obtained by administering questionnaires and interviewing targeted respondents. A mix of 
quantitative and qualitative methods of data analysis was employed. Quantitative analysis was applied to the regression model, while qualitative analysis was applied to all other non-quantitative questions and variables. SPSS and STATA statistical packages were employed in descriptive analysis and estimation of the variance respectively.

\section{Presentation and Discussion of Results}

This section presents the analyses of the data collected and the discussions thereof.

\subsection{Demographic Characteristics of the sample}

The demographic characteristics of the people involved in this study are presented in Table 1 below.

Table 1. Demographic characteristics of the sample

\begin{tabular}{|c|c|c|c|c|c|}
\hline \multirow[t]{2}{*}{ Variables } & \multirow[t]{2}{*}{ Type } & \multirow{2}{*}{$\begin{array}{l}\text { Staff } \\
\text { Frequency }\end{array}$} & \multicolumn{3}{|c|}{ Clients } \\
\hline & & & Percentage & Frequency & Percentage \\
\hline \multirow[t]{2}{*}{ Gender } & Female & 17 & 37.80 & 20 & 44.40 \\
\hline & Male & 28 & 62.20 & 25 & 55.60 \\
\hline Total & & 45 & 100.00 & 45 & 100.00 \\
\hline \multirow[t]{3}{*}{ Age (Years) } & $26-33$ & 13 & 28.90 & 7 & 15.60 \\
\hline & $34-41$ & 23 & 51.10 & 25 & 55.60 \\
\hline & $42-49$ & 9 & 20.00 & 13 & 28.80 \\
\hline Total & & 45 & 100.00 & 45 & 100.00 \\
\hline \multirow[t]{3}{*}{ Education } & High School & - & - & 27 & 60.00 \\
\hline & First Degree & 37 & 82.20 & 15 & 33.30 \\
\hline & Masters & 8 & 17.80 & 3 & 6.70 \\
\hline Total & & 45 & 100.00 & 45 & 100.00 \\
\hline Marital & Single & 6 & 13.30 & 3 & 6.70 \\
\hline Status & Married & 39 & 86.70 & 42 & 93.30 \\
\hline Total & & 45 & 100.00 & 45 & 100.00 \\
\hline
\end{tabular}

Table 1 shows that the staff of the MFIs was made up of 17 (37.80\%) males and $28(62.20 \%)$ females. The clients were made up of $20(44.40 \%)$ males and $25(55.60 \%)$ females. The results also revealed that $13(28.90 \%)$ of the staff of the MFIs were aged between 26 and 33, the same as $7(15.60 \%)$ of the clients. Also, $23(51.10 \%)$ of the staff and $25(55.60 \%)$ of the clients were aged between 34 and 41. Lastly, $9(20.00 \%)$ of the staff, as well as 13 (28.85) of the clients, were aged between 42 and 49 . The results further revealed that $27(60.00 \%)$ of the clients of the MFIs have only reached the senior high school level informal education. Those who have acquired a first degree included $37(82.20 \%)$ of the staff as well as $15(33.30 \%)$ of the clients. Lastly, $8(17.80 \%)$ of the staff and $3(6.70 \%)$ of the clients also asserted that they had acquired a master's degree. It is also evident that most 39 (86.70\%) of the MFI staff were married whiles $6(13.30 \%)$ were single. For the MFI clients engaged in this study, 43 (93.30\%) were married 
whiles $3(6.70 \%)$ were single.

\subsection{Challenges Facing MFIs}

The responses of the staff on flaws bedeviling the operations of MFIs were rated on a 5-point Likert scale (1. Very negative, 2. Negative, 3. No effect, 4. Positive, 5. Very positive). Since the potential challenges that could be facing an MFI are numerous, the researchers categorized the various challenges that could be faced by the MFIs.

\subsubsection{Corporate Governance}

The first area of the operation of the MFIs, which was assessed for the presence of challenges was corporate governance. The results are presented in the table below.

Table 2. Descriptive Statistics (Corporate Governance)

\begin{tabular}{lccccc}
\hline Best Practices & N & Mean & $\begin{array}{c}\text { Standard } \\
\text { Deviation }\end{array}$ & Skewness & Kurtosis \\
\hline Laid down procedures to guide duties of staff. & 45 & 3.7111 & 1.25449 & -1.445 & 1.028 \\
Management enforces compliance with guidelines. & 45 & 3.8889 & 0.93474 & -0.994 & 0.366 \\
Sanctions are applied for flouting such guidelines & 45 & 3.3556 & 1.19003 & -0.910 & 0.106 \\
$\begin{array}{l}\text { Guidelines are obeyed by managers, as well. } \\
\text { Loan applications are reviewed and approved by the } \\
\text { credit committee }\end{array}$ & 45 & 2.9778 & 1.23378 & -0.108 & -0.855 \\
Total & & 3.0667 & 1.26850 & -0.270 & -1.010 \\
\hline
\end{tabular}

According to the results, generally, the staff of the MFIs believe their respective institutions have in place the required best practices that would ensure effective corporate governance. This is indicated by the overall mean of 3.4000; and a standard deviation of 1.10124, which also indicates that their responses are fairly spread out around the mean. The respondents agreed that their respective MFIs take the appropriate steps regarding the major best practices; that is having in place laid down procedures that guide and determine the duties of the staff (mean: 3.7111; standard deviation: 1.25449); enforcing the compliance with such guidelines (mean: 3.8889; standard deviation: 0.93474); sanctioning those who flout such guidelines (mean: 3.3556; standard deviation: 1.19003); and ensuring that loans are reviewed and approved by the credit committee (mean: 3. 0667; standard deviation: 1.26850). However, the results revealed that the majority of the people do have a problem when it comes to managers complying with the guidelines. The mean of 2.9778 indicates that generally, the staff do not think managers of the MFIs comply with the guidelines issued to guide the performance of duties of the staff. A standard deviation of 1.23378 indicated that their views are fairly spread out around the mean. In other words, the first challenge identified by this study regarding the operations of MFIs when it comes to corporate governance is the belief that managers of the MFIs, unlike their staff, do not abide by the guidelines set out to regulate the job description of staff of the MFIs.

An analysis of variance (ANOVA) test was carried out to find out whether there was a 
statistically significant difference between their perceptions. The results are presented in the table below.

Table 3. ANOVA (Corporate Governance)

\begin{tabular}{llllll}
\hline & Sum of Squares & df & Mean Square & F & Sig. \\
\hline Between Groups & 0.837 & 2 & 0.419 & 0.335 & 0.717 \\
Within Groups & 52.523 & 42 & 1.251 & & \\
Total & $\mathbf{5 3 . 3 6 0}$ & $\mathbf{4 4}$ & & & \\
\hline
\end{tabular}

The significance value ( $p$-value) set for the test was $p \leq 0.05$, which measures statistical significance. Since the figure in the significance column in the table above $(0.717)$ is way higher than 0.05 , it could be concluded that there is no statistically significant difference between the views expressed by the staff of the three MFIs involved in the study.

\subsubsection{Credit Risk Management and Credit Administration}

The second area of the operation of the MFIs which was assessed for the presence of challenges was the area of credit risk management and credit administration. The results are presented below.

Table 4. Descriptive statistics (credit risk management and credit administration)

\begin{tabular}{|c|c|c|c|c|c|}
\hline Best Practices & $\mathbf{N}$ & Mean & $\begin{array}{l}\text { Std. } \\
\text { Deviation }\end{array}$ & Skewness & Kurtosis \\
\hline $\begin{array}{l}\text { All borrowers pay back loans on time as } \\
\text { agreed. }\end{array}$ & 45 & 2.6444 & 1.43266 & 0.229 & -1.391 \\
\hline $\begin{array}{l}\text { A lot of resources are used to recover } \\
\text { delayed loans. }\end{array}$ & 45 & 3.6889 & 1.32840 & -1.098 & 0.179 \\
\hline $\begin{array}{l}\text { Most Clients do use loans for } \\
\text { intended purpose. }\end{array}$ & 45 & 2.8222 & 1.46612 & -0.085 & -1.536 \\
\hline $\begin{array}{l}\text { Clients provide adequate collateral } \\
\text { before receiving loans. }\end{array}$ & 45 & 3.4000 & 1.38826 & -0.664 & -0.966 \\
\hline $\begin{array}{l}\text { Clients invest the loans in their } \\
\text { business/start new business. }\end{array}$ & 45 & 2.6856 & 1.44320 & 0.149 & -1.4451 \\
\hline $\begin{array}{l}\text { Due process is followed in advancing } \\
\text { credit to board member. }\end{array}$ & 45 & 2.9778 & 1.23378 & -0.108 & -0.855 \\
\hline Total & 45 & 3.0370 & 1.23086 & -0.246 & -0.806 \\
\hline
\end{tabular}

According to the results, generally, the staff of the MFIs have a very weak positive perception of the effectiveness of credit risk management and credit administration in their respective institutions. This is indicated by the overall mean of 3.0370; and a standard deviation of 1.23086 which also indicates that their responses are fairly spread out around the mean. The results also revealed that the staff of the MFIs agree with only two practices regarding credit risk and credit administration in the institutions: the use of a lot of institutional resources in recovering delayed loans (mean: 3.6889; standard deviation: 1.32840), and ensuring that 
clients provide adequate collateral before receiving loans from the institutions (mean: 3.4000; standard deviation: 1.38826). However, the respondents do not agree with the suggestion that all borrowers pay back loans on time as agreed (mean: 2.6444; standard deviation: 1.43266). They also do not support the suggestion that most of their clients do use loans for intended purpose (mean: 2.8222; standard deviation: 1.46612) neither do they agree with the suggestion that their clients always invest loans provided for them by the MFIs in expanding or starting their businesses (mean: 2.6856: standard deviation: 1.44320). As well, they do not accept the suggestion that due process is always followed in advancing credit facilities to board members of the bank (mean: 2.9778; standard deviation: 1.23378). In other words, the MFIs could be said to face challenges when it comes to the above issues when it comes to credit risk and credit administration in the institutions. An analysis of variance (ANOVA) test was carried out to find out whether there was a statistically significant difference between their perceptions. The results are presented in the table below.

Table 5. Analysis of Variance

\begin{tabular}{llllll}
\hline & Sum of Squares & df & Mean Square & F & Sig. \\
\hline Between Groups & 1.009 & 2 & 0.504 & 0.335 & 0.726 \\
Within Groups & 65.652 & 42 & 1.563 & & \\
Total & $\mathbf{6 6 . 6 6 0}$ & $\mathbf{4 4}$ & & & \\
\hline
\end{tabular}

The significance value ( $\mathrm{p}$-value) set for the test was $\mathrm{p} \leq 0.05$ which measures statistical significance. Since the figure in the significance column in the table above $(0.726)$ is way higher than 0.05 , it could be concluded that there is no statistically significant difference between the views expressed by the staff of the three MFIs involved in the study.

\subsubsection{Regulatory Issues}

The third area which was assessed for the presence of challenges borders on the regulatory issues in the operations of the MFIs. The results are presented below.

Table 6. Descriptive statistics (regulatory issues)

\begin{tabular}{llllll}
\hline Best Practices & $\mathbf{N}$ & Mean & Std. Deviation & Skewness & Kurtosis \\
\hline $\begin{array}{l}\text { All employees are aware of regulations } \\
\text { governing the organisation }\end{array}$ & 45 & 3.6100 & 1.26850 & -1.144 & 0.364 \\
$\begin{array}{l}\text { BoG has rigid supervisory system that } \\
\text { monitors your organisations regularly. }\end{array}$ & 45 & 3.4889 & 1.19891 & -1.215 & 0.527 \\
$\begin{array}{l}\text { The regulator (BoG) has adequate capacity } \\
\text { to monitor your activities. }\end{array}$ & 45 & 2.5333 & 1.35848 & 0.410 & -0.986 \\
$\begin{array}{l}\text { BoG punishes your MFI with huge fines } \\
\text { for flouting any regulation. }\end{array}$ & 45 & 3.0210 & 1.26131 & -0.142 & -1.013 \\
$\begin{array}{l}\text { BoG has guidelines that require MFIs to } \\
\text { protect deposits of their clients. }\end{array}$ & 45 & 3.3313 & 1.25131 & -0.814 & -0.506 \\
Total & $\mathbf{4 5}$ & $\mathbf{3 . 1 9 1 1}$ & $\mathbf{1 . 1 2 0 8 4}$ & $\mathbf{- 0 . 6 8 6}$ & 0.375 \\
\hline
\end{tabular}


According to the results, generally, the staff of the MFIs have a weak positive perception of the effectiveness of regulatory issues as they pertain to the operations of MFIs. This is indicated by the overall mean of 3.1911; and a standard deviation of 1.12084 which also indicates that their responses are fairly spread out around the mean. The results also revealed that the staff of the MFIs have a positive perception regarding all but one of the parameters used to assess the effectiveness of regulatory issues with regards to MFIs. The results revealed that the staff have a positive perception of the suggestion that all employees are aware of the regulations that govern their various organisation's operations (mean: 3.6100; standard deviation: 1.26850); that the regulator $(\mathrm{BoG})$ has a rigid supervisory system that monitors the activities of their respective organisations regularly (mean: 3.4889; standard deviation: 1.19891); and that the regulator issues guidelines that require MFIs to protect deposits of their clients (mean: 3.3313; standard deviation: 1.25131). The respondents also expressed a very weak positive perception with regards to the suggestion that the regulator punishes MFIs with huge fines if they flout any of the regulations (mean: 3.0210; standard deviation: 1.26131). However, the respondents do not agree with the suggestion that the regulator $(\mathrm{BoG})$ has the adequate capacity to monitor the activities of the MFIs in the country (mean: 2.5333; standard deviation: 1.35848). This implies that another challenge facing the microfinance industry in the country is the lack of the capacity of the industry regulator (BoG) to effectively monitor the activities of all MFIs in the country.

An analysis of variance (ANOVA) test was carried out to find out whether there was a statistically significant difference between their perceptions. The results are presented in the table below.

Table 7. Analysis of variance

\begin{tabular}{llllll}
\hline & Sum of Squares & df & Mean Square & F & Sig. \\
\hline Between Groups & 0.732 & 2 & 0.366 & 0.282 & 0.756 \\
Within Groups & 54.544 & 42 & 1.299 & & \\
Total & $\mathbf{5 5 . 2 7 6}$ & $\mathbf{4 4}$ & & & \\
\hline
\end{tabular}

The significance value ( $\mathrm{p}$-value) set for the test was $\mathrm{p} \leq 0.05$ which measures statistical significance. Since the figure in the significance column in the table above $(0.756)$ is way higher than 0.05 , it could be concluded that there is no statistically significant difference between the views expressed by the staff of the three MFIs involved in the study.

\subsubsection{Non Performing Loans}

The fourth area assessed by the researcher for challenges with the operations of MFIs was non-performing loans. The results are presented in the table below. 
Table 8. Descriptive statistics (non-performing loans)

\begin{tabular}{|c|c|c|c|c|c|}
\hline Best Practices & $\mathbf{N}$ & Mean & $\begin{array}{l}\text { Std. } \\
\text { Deviation }\end{array}$ & Skewness & Kurtosis \\
\hline Not all clients do pay back their loans on time. & 45 & 3.3556 & 1.52488 & -0.598 & -1.132 \\
\hline $\begin{array}{l}\text { Delayed payment of loans affects the financial } \\
\text { performance of your MFI. }\end{array}$ & 45 & 3.5778 & 1.25207 & -1.166 & 0.422 \\
\hline $\begin{array}{l}\text { Cost of recovering delayed loans is expensive to } \\
\text { your organisation. }\end{array}$ & 45 & 3.6889 & 1.32840 & -1.098 & 0.179 \\
\hline $\begin{array}{l}\text { Your organisation has not taken enough steps to } \\
\text { recover all unpaid loans. }\end{array}$ & 45 & 2.7333 & 1.21356 & 0.142 & -1.012 \\
\hline Total & 45 & 3.3389 & 1.17763 & -0.940 & 0.095 \\
\hline
\end{tabular}

According to the results, generally, the staff of the MFIs generally agreed with the views suggested during the assessment. This was indicated by the overall mean of 3.3389; and a standard deviation of 1.17763 which also indicates that their responses are fairly spread out around the mean. Specifically, the respondents agreed that not all clients pay back their loans on time (mean: 3.3556; standard deviation: 1.52488); that delayed payment of loans affects the financial performance of their respective MFIs (mean: 3.5778; standard deviation: 1.25207); and that the cost of recovering delayed loans is expensive to their organisations (mean: 3.6889; standard deviation: 1.32840). However, the staff do not agree with the suggestion that their financial institutions do not take enough steps to recover all unpaid loans (mean: 2.7333; standard deviation: 1.21356). In other words, three major challenges were identified with the operations of the MFIs when it comes to preventing the incidence of non-performing loans. Specifically, the findings revealed that not all clients of the MFIs pay back what they owe the institutions, that delayed payment of loans affects the financial performance of MFIs, and that the cost of recovering delayed loans is expensive to MFIs. An analysis of variance (ANOVA) test was carried out to find out whether there was a statistically significant difference between their perceptions. The results are presented in the table below.

Table 9. Analysis of variance

\begin{tabular}{llllll}
\hline & Sum of Squares & df & Mean Square & F & Sig. \\
\hline Between Groups & 0.544 & 2 & 0.272 & 0.189 & 0.828 \\
Within Groups & 60.475 & 42 & 1.440 & & \\
Total & $\mathbf{6 1 . 0 1 9}$ & $\mathbf{4 4}$ & & & \\
\hline
\end{tabular}

The significance value ( $p$-value) set for the test was $p \leq 0.05$ which measures statistical significance. Since the figure in the significance column in the table above $(0.828)$ is way higher than 0.05 , it could be concluded that there is no statistically significant difference between the views expressed by the staff of the three MFIs involved in the study. 


\subsubsection{Training Programs}

The last area where the study assessed in an attempt to identify the challenges facing the MFIs was training programmes for the staff of the microfinance institutions. The results are presented in the table below.

Table 10. Descriptive statistics (training programmes)

\begin{tabular}{lccccc}
\hline Best Practices & N & Mean & $\begin{array}{l}\text { Std. } \\
\text { Deviation }\end{array}$ & Skewness & Kurtosis \\
\hline $\begin{array}{l}\text { Your organisation has training programmes for } \\
\text { employees. }\end{array}$ & 45 & 3.6889 & 1.32840 & -1.098 & 0.179 \\
$\begin{array}{l}\text { Your organisation has organised at least one training } \\
\text { programme for employees this year. }\end{array}$ & 45 & 3.4869 & 1.35885 & -0.857 & -0.605 \\
$\begin{array}{l}\text { Your organisation takes care of the full cost of all the } \\
\text { training programmes. }\end{array}$ & 45 & 3.5111 & 1.19891 & -1.270 & 0.628 \\
$\begin{array}{l}\text { Industry experts are brought from outside your firm to } \\
\text { train employees. }\end{array}$ & 45 & 3.2222 & 1.34653 & -0.309 & -1.010 \\
$\quad$ & $\mathbf{4 5}$ & $\mathbf{3 . 4 7 7 8}$ & $\mathbf{1 . 2 1 4 0 5}$ & $\mathbf{- 1 . 0 5 1}$ & $\mathbf{0 . 4 0 7}$ \\
\hline
\end{tabular}

According to the results, generally, the staff of the MFIs generally agreed with the views suggested with regards to training issues in their institutions. This was indicated by the overall mean of 3.4778; and a standard deviation of 1.21405 which also indicates that their responses are fairly spread out around the mean. The various institutions were found to have in place all the expected standards as far as training activities for their staff are concerned. For instance, the results revealed that the MFIs have in place the expected training programmes for their staff (mean: 3.6889; standard deviation: 1.32840). They were also found to organise at least one training programme for their staff each year (mean: 3.4869; standard deviation: 1.35885), take care of the full cost of all the training programmes (mean: 3.5111; standard deviation: 1.19891), and finally, the services of industry experts during such training programmes to ensure their staff are given the required knowledge (mean: 3.2222; standard deviation: 1.34653). In other words, the MFIs were not found to be facing any serious challenge when it comes to training issues regarding their operations. The results of this study suggest that MFIs in the country are fully aware of the above requirements and have taken steps to ensure such training sessions are given to their employees. An analysis of variance (ANOVA) test was carried out to find out whether there was a statistically significant difference between their perceptions. The results are presented in the table below.

Table 11. Analysis of variance

\begin{tabular}{llllll}
\hline & Sum of Squares & df & Mean Square & F & Sig. \\
\hline Between Groups & 0.636 & 2 & 0.318 & 0.208 & 0.813 \\
Within Groups & 64.217 & 42 & 1.529 & & \\
Total & $\mathbf{6 4 . 8 5 3}$ & $\mathbf{4 4}$ & & & \\
\hline
\end{tabular}




\section{$\Lambda$ Macrothink}

The significance value ( $p$-value) set for the test was $\mathrm{p} \leq 0.05$ which measures statistical significance. Since the figure in the significance column in the table above (0.813) is way higher than 0.05 , it could be concluded that there is no statistically significant difference between the views expressed by the staff of the three MFIs involved in the study regarding the issue of training programmes for their staff.

\subsection{Challenges Facing Clients of MFIs}

The second objective of this study was to determine challenges of the clients who access micro credit facilities. To achieve this objective, questionnaires were administered to 45 clients of the three microfinance institutions on which the study focused. The responses of the clients were rated on a 5-point Likert scale (1. Strongly disagree, 2. Disagree, 3. Somehow agree, 4. Agree, 5. Strongly agree). The results revealed five major challenges facing the clients of MFIs which have been presented in Table 12.

Table 12. Challenges facing clients of MFIs (CFCM)

\begin{tabular}{|c|c|c|c|c|c|c|c|c|}
\hline \multirow[t]{2}{*}{ Challenge } & \multicolumn{5}{|c|}{ Frequency } & \multirow[t]{2}{*}{$\mathbf{N}$} & \multirow[t]{2}{*}{ Mean } & \multirow{2}{*}{$\begin{array}{l}\text { Standard } \\
\text { Deviation }\end{array}$} \\
\hline & $\begin{array}{l}\text { Strongly } \\
\text { Disagree } \\
1\end{array}$ & $\begin{array}{l}\text { Disagree } \\
2\end{array}$ & $\begin{array}{l}\text { Neutral } \\
\mathbf{3}\end{array}$ & $\begin{array}{l}\text { Agree } \\
4\end{array}$ & $\begin{array}{l}\text { Strongly } \\
\text { Agree } \\
5\end{array}$ & & & \\
\hline CFCM -1 & 2 & 10 & 6 & 16 & 11 & 45 & 3.53 & 1.3192 \\
\hline CFCM -2 & 4 & 6 & 6 & 15 & 14 & 45 & 3.64 & 1.4327 \\
\hline CFCM -3 & 2 & 4 & 9 & 14 & 16 & 45 & 3.84 & 1.3577 \\
\hline CFCM -4 & 3 & 6 & 2 & 14 & 20 & 45 & 3.93 & 1.2227 \\
\hline CFCM -5 & 1 & 4 & 10 & 14 & 16 & 45 & 3.89 & 1.3238 \\
\hline
\end{tabular}

\section{Key to Table 12}

CFCM-1: Loan processing takes too long

CFCM-2: No training or advice from MFI

CFCM-3: High interest rates

CFCM-4: Negative impact of short loan repayment terms

\section{CFCM-5: Demand for collateral}

The first challenge identified by this study was the length of time it takes the bank to approve loans for its customers. As could be seen from the table above, 1 client (2.22\%) strongly disagreed to the statement that loan processing time by the MFIs takes too long; $4(8.89 \%)$ disagreed; $10(22.22 \%)$ expressed a neutral view; 14 (31.11\%) agreed while the remaining 16 $(35.56 \%)$ strongly agreed. The results revealed a mean of 3.53 (approximately 4 ), an indication that generally, the respondents agreed that the time the MFIs take to process loans is too long. A standard deviation of 1.3192 also indicated that their responses are fairly spread out around the mean. 
The second challenge identified has to do with whether the MFIs train or give their clients some form of advice on how to use the credit facility provided for them by the MFI. As could be seen from the table above, 4 clients $(8.89 \%)$ strongly disagreed to the statement that the MFIs do not train or give their clients some form of advice on how to use the credit facility provided for them by the MFI; 6 (13.33\%) disagreed; 6 (13.33\%) expressed a neutral view; 15 $(33.33 \%)$ agreed while the remaining $14(31.11 \%)$ strongly agreed. The results also revealed a mean of 3.64 (approximately 4.00), an indication that generally, the respondents agreed that the MFIs do not train or give their clients some form of advice on how to use the credit facility provided for them by the MFIs. A standard deviation of 1.4327 also indicates that their responses were fairly spread out around the mean.

The third challenge identified by this study as a challenge that clients face in their attempt to access microcredit was high-interest rates. As could be seen from the table above, 2 clients (4.44\%) strongly disagreed that the interest rates charged by MFIs are too high; $4(8.89 \%)$ disagreed; 9 (20.00\%) expressed a neutral view; 14 (31.11\%) agreed while the remaining 16 of them $(35.56 \%)$ strongly agreed. The results also revealed a mean of 3.84 (approximately 4.00 ), an indication that generally, the respondents agree that the interest rate the MFIs charges are too high. A standard deviation of 1.3577 also indicated that their responses are fairly spread out around the mean.

The fourth challenge facing clients of MFIs in this study is the impact of short repayment periods on the success of the businesses of the clients. As could be seen from the table above, 3 clients $(6.67 \%)$ strongly disagreed that short period of repayment negatively affects their businesses; 6 (13.33\%) disagreed; 2 (4.44\%) expressed a neutral view; 14 (31.11\%) agreed while the remaining $20(44.44 \%)$ strongly agreed. The results also revealed a mean of 3.93 (approximately 4.00), an indication that generally, the respondents agreed to a large extent that the short repayment terms given by MFIs affect the financial performance of the businesses of their clients. A standard deviation of 1.2227 also indicated that their responses are fairly spread out around the mean.

The last challenge which clients face in their attempt to access microcredit from the MFIs, according to the results of this survey, is the issue of collateral demanded by the MFIs. As could be seen from the table above, 1 client $(2.22 \%)$ strongly disagreed to the statement - clients face difficulty in coming up with the collateral demanded by MFIs when client request bigger amounts; 4 (8.89\%) disagreed; 10 (22.22\%) expressed a neutral view; 14 (31.11\%) agreed while the remaining $16(35.56 \%)$ strongly agreed. The results revealed a mean of 3.89 (approximately 4.00), an indication that generally, the respondents agreed quite forcefully that clients face difficulty in coming up with the collateral demanded by MFIs when client request bigger amounts. A standard deviation of 1.3238 also indicates that their responses are fairly spread out around the mean.

\subsection{Effect of Flaws and Challenges on Operational Performance}

The last objective of this study was to assess the effect of the flaws and challenges identified with the operations of MFIs on the operational performance of the MFIs, so a regression analysis was carried out to find out how the flaws impact on the financial performance, 
efficiency of internal structures and level of customer satisfaction in the operations of the MFIs. The results are presented in the series of tables below.

Table 13. Descriptive statistics

\begin{tabular}{llll}
\hline & Mean & Std. Deviation & N \\
\hline Overall effects on performance & 2.1094 & 0.70872 & 45 \\
Flaws and Challenges & 2.7683 & 1.26399 & 45 \\
\hline
\end{tabular}

The descriptive statistics table above presents the results regarding the mean and standard deviation of the variables used in the analysis. As could be noticed, an overall mean of 2.1094 indicates that the flaws and challenges faced by the MFIs do harm the overall operational performance of the MFIs. The mean of 2.7683 and standard deviation of 1.26399 are just an indication of the already established finding that the MFIs do face flaws and challenges.

Table 14. Correlations

\begin{tabular}{llll}
\hline & & $\begin{array}{l}\text { Overall effects on } \\
\text { performance }\end{array}$ & $\begin{array}{l}\text { Flaws and } \\
\text { Challenges }\end{array}$ \\
\hline Pearson & Overall effects on performance & 1.000 & 0.148 \\
Correlation & Flaws and Challenges & 0.148 & 1.000 \\
Sig. (1-tailed) & Overall effects on performance & - & 0.166 \\
& Flaws and Challenges & 0.166 & - \\
$\mathrm{N}$ & Overall effects on performance & 45.000 & 45.000 \\
& Flaws and Challenges & 45.000 & 45.000 \\
\hline
\end{tabular}

The results from the correlations, as presented in the table above reveals a correlation coefficient of 0.148 . The figure, being positive, indicated a positive correlation between the two variables. A positive correlation between the two variables indicates that when the flaws and challenges faced by the MFIs increase, the negative impact on the operational performance of the MFIs also increases.

Table 15. Model summary

\begin{tabular}{lllll}
\hline Model & R & R square & Adjusted R Square & Std. Error of the Estimate \\
\hline 1 & 0.148 & 0.022 & -0.001 & 0.70905 \\
\hline
\end{tabular}

The table above presents results regarding how much impact the flaws and challenges faced by the MFIs have on their operational performance. This is indicated in the column labeled " $\mathrm{R}$ Square". The figure in that column is 0.022 , which translates into $2.20 \%$ if converted into percentages. Therefore, per the regression analysis, the current flaws and challenges faced by the MFIs has a $2.20 \%$ impact on their operational performance. ANOVA was performed to find 
out whether such a level of impact is statistically significant or not, and the results are as follows.

Table 16. Analysis of variance

\begin{tabular}{llllll}
\hline & Sum of squares & df & Mean square & F & Sig. \\
\hline Regression & 0.482 & 1 & 0.482 & 0.959 & 0.333 \\
Residual & 21.618 & 43 & 0.503 & & \\
Total & $\mathbf{2 2 . 1 0 0}$ & $\mathbf{4 4}$ & & & \\
\hline
\end{tabular}

From the table above, it could be noticed that the significance value (p-value) shown under the column labeled "Sig." is 0.333 . Since this figure is higher than the p-value set during the regression analysis (which was $\mathrm{p} \leq 0.05$ ), it could be concluded that the impact of the flaws faced by the MFIs on their operational performance was not statistically significant. Thus, even though it could be concluded that the flaws and challenges faced by the MFIs do impact negatively on their operational performance, such an impact is not statistically significant.

\section{Conclusion and Recommendations}

The results discovered challenges with the operations of the MFIs in some specific areas including failure of managers to comply with laid down guidelines regarding employee behaviour, failure of borrowers to pay back loans on time, failure of clients to use loans for the intended purposes, failure to follow due process in advancing credit facilities to top management of the MFIs, lack of resources for the BoG to use in effectively monitoring activities of MFIs in the country, the negative impact of delayed payment of loans on the financial performance of the MFIs, and lastly, the negative impact of the cost of recovering non-performing loans on the financial performance of the MFIs.

The clients of the MFIs were also found to have some challenges when it comes to their dealings with the MFIs. It was discovered that generally, the clients of the MFIs believe the loan granting process of the MFIs takes too long, MFIs do not give professional advice to the clients as to how to use the credit facility provided for them by the MFIs, high rate of interest charged on the credit facilities given out by the MFIs, short repayment terms given by MFIs negatively affecting the financial performance of the businesses of the clients, and lastly, the difficulty faced by clients in coming up with the collateral demanded by the MFIs when clients demand higher loan amount from the MFIs. These were the major challenges identified by the study as those that affect the clients in their dealings with the MFIs.

This study also revealed that operational flaws and challenges do harm the overall performance of the MFIs. The results also indicated that when such flaws and challenges increase, their impact become more severe, that is, when the flaws and challenges increase, the negative impact also increases. Finally, the results also revealed that even though such flaws and challenges do impact on the operational performance of the MFIs, the impact is not statistically significant. 
Based on the findings of this study, the following recommendations are made for consideration by the appropriate authorities. As much as possible, the boards of the MFIs should have powers that can enable the boards diffuse influence on a single individual (especially the founder of the MFI) on certain issues particularly with regards to corporate governance and credit administration. The MFIs must ensure that they have in place well-composed and resourceful credit committee who perform the duty of credit risk management in the organisation. It is also advisable that MFIs expedite the procedure for granting credit facilities to clients. Since it has also been found out that the process of granting credit facilities also depends on the ability of the clients to quickly provide the requirements demanded by the MFIs, clients also needed to be encouraged to make such requirements available to the MFIs as quickly as possible. The MFIs must be encouraged to reduce their interest rates as well as the quantum of collateral they demand from clients before advancing credit facilities to them. Apparently, it is recommended that the MFIs take all necessary steps to ensure that they reduce the flaws and challenges they face. Statistical tests provide evidence that if the flaws and challenges they face increases, the impact on their operational performance, which was found to be negative, also increases. Even though the impact of such flaws and challenges might not be statistically significant at the moment, they may become statistically significant if the flaws and challenges faced by the MFIs increase. Lastly, for lack of resources, the study was conducted with a small sample size; thus, future studies on this topic could be engineered with very large sample size.

\section{References}

Addai, B. (2017). Women empowerment through microfinance: Empirical evidence from Ghana. Journal of Finance and Accounting, 5(1), 1-11.

Anitha, C., \& Reddy, D. R. (2017). Evolution and Emerging Role of MFIs in Indian Microfinance Sector. Sumedha Journal of Management, 6(4), 87-105.

Arku, R. E., Bennett, J. E., Castro, M. C., Agyeman-Duah, K., Mintah, S. E., Ware, J. H., ... \& Ezzati, M. (2016). Geographical inequalities and social and environmental risk factors for under-five mortality in ghana in 2000 and 2010: Bayesian spatial analysis of census data. PLoS medicine, 13(6), e1002038.

Asiama P. and Osei V. (2007) Microfinance in Ghana: An overview. Research Department Bank of Ghana, Economic Web Institute.

Bertocco, G. (2007). Some Observations about the Loanable Funds Theory. Economics and Quantitative Methods, Department of Economics, University of Insubria.

Boateng, A. A. (2015). An examination of challenges and prospects of microfinance institutions in Ghana. Journal of Economics and Sustainable Development, 6(4), 52-60.

CGAP. (2015). Microfinance FAQs. Retrieved from http://www.microfinancegateway.org/what-is-microfinance

Couchoro, M. K. (2016). Challenges faced by MFIs in adopting management information systems during their growth phase: the case of Togo. Enterprise Development and Microfinance, 27(2), 115-131. 
Dato, M. H., Mersland, R., \& Mori, N. (2018). Board committees and performance in microfinance institutions: Evidence from Ethiopia. International Journal of Emerging Markets, 13(2), 350-370.

Donou-Adonsou, F., \& Sylwester, K. (2016). Financial development and poverty reduction in developing countries: New evidence from banks and microfinance institutions. Review of Development Finance, 6(1), 82-90.

Egyir I. S. (2010). Rural Women and Microfinance in Ghana: Challenges and Prospects. Contributed Paper presented at the Joint 3rd African Association of Agricultural Economists (AAAE) and 48th Agricultural Economists Association of South Africa (AEASA) Conference, Cape Town, South Africa, September 19-23, 2010

Ferrando, A., Popov, A., \& Udell, G. F. (2017). Sovereign stress and SMEs' access to finance: Evidence from the ECB's SAFE survey. Journal of Banking and Finance, 81, 65-80.

Flora, K. A. (2015). The Challenges Confronting Small Scale Businesses in accessing Microfinance Services from MFIs Case Study: Rural Tanzania. International Journal of Academic Research in Business and Social Sciences, 5(11), 299-311.

Friends Consult. (2015). FAQs about Microfinance Capacity Building. Retrieved March 8, 2015 , from http://www.friendsconsult.co.ug/index.php/2013-05-03-00-58-34/microfinance-capacity-buil ding

J-PAL. (2014). Theory of Change. Retrieved from https://www.povertyactionlab.org /sites/default/files/event/Lecture\%25202-THEORY\%2520OF\%2520CHANGE.pdf\&ved=2ah UKEwiAmuT_kdrkAhUPJVAKHb8CBWoQFjAKegQIAhAB\&usg=AOvVaw316YOtMvXH70ovFOrAirt.

Kumar, A., \& Conteh, A. (2015). Common frauds in micro finance institutions (MFIs). Internationnal Journal of Advanced Rural Management, 1(1), 11-18.

Loanadble fund http://kokminglee.125mb.com/economics/loanablefund.html

Mia, M. A. (2017). Interest rate caps in microfinance: Issues and challenges. The Journal of Industrial Distribution \& Business, 8(3), 19-22.

Mukama, J., Fish, T., \&, Volschenk, J. (2005). Problems affecting the growth of Microfinance Institutions in Tanzania. The African Finance Journal, 7(Part 2).

Okezie, A. I., Bankoli, B., \& Ebomuche, N. C. (2014). The Impact of Nigeria Microfinance Banks on Poverty Reduction: Imo State Experience. International Letters of Social and Humanistic Sciences, 16, 92-113.

Owusu-Nuamah, P. (2014). Collapse of microfinance companies - Companies shot themselves in the foot. Retrieved March 1, 2018, from http://microfinanceafrica.net/news/ghana-collapse-of-microfinance-companiescompanies-sho t-themselves-in-the-foot 


\section{Macrothink}

Shah, R. J., \& Patel, A. B. (2017). Micro-finance in India: Strategies to overcome operational issues and challenges. International Journal of Advanced Research in Management and Social Sciences, 6(2), 90-101.

Stein, D., \& Valters, C. (2012). Understanding theory of change in international development. JSRP Working Paper 1, A Justice and Security Research Programme (JSRP) and the Asia Foundation (TAF) collaborative project, London.

Wulandari, P., \& Kassim, S. (2016). Issues and challenges in financing the poor: case of Baitul Maal Wa Tamwil in Indonesia. International Journal of Bank Marketing, 34(2), 216-234.

\section{Copyrights}

Copyright for this article is retained by the author(s), with first publication rights granted to the journal.

This is an open-access article distributed under the terms and conditions of the Creative Commons Attribution license (http://creativecommons.org/licenses/by/4.0/). 